\title{
Restless behavior increases over time, but not with compressibility of the flooring surface, during forced standing at the feed bunk
}

\author{
N. Krebs, S. L. Berry, and C. B. Tucker ${ }^{1}$ \\ Department of Animal Science, University of California, 1 Shields Avenue, Davis 95616
}

\begin{abstract}
Interest in the use of rubber flooring in freestall barns has increased, but little is known about which design features of these surfaces are important for cattle. In 2 experiments, we evaluated how the type and compressibility of the flooring surface in front of the feed bunk influenced the behavioral response to 4 $\mathrm{h}$ of forced standing after morning milking. Two flooring types were compared: rubber and concrete. Rubber was tested at 3 levels of compressibility: 2, 4, and 35 times as compressible as concrete. Four hours of forced standing was evaluated because it mimicked conditions that can occur on dairies, particularly when waiting for artificial insemination or veterinary treatment. The effects of cow weight and hoof surface area, gait score, and hoof health on the response to treatment were evaluated. Restless behavior, as measured by number of steps, almost doubled over the $4 \mathrm{~h}$ of forced standing, regardless of flooring material. Cows lay down, on average, within 5 min after access to the lying area was provided. These results indicate that the $4 \mathrm{~h}$ of forced standing was uncomfortable. No differences in restless behavior were observed in association with the type or compressibility of the flooring surface in front of the feed bunk. Cow size, hoof health, or gait score did not consistently explain the response to the flooring treatments or stepping rate, although these populations of animals were generally healthy. It is unclear if comfort did not differ between the flooring options tested during $4 \mathrm{~h}$ of forced standing or if alterative methodology, such as measuring more subtle shifts in weight, is required to assess design features of rubber flooring.
\end{abstract}

Key words: behavior, flooring, restless, restraint

\section{INTRODUCTION}

Dairy cows are often housed on concrete floors (USDA, 2007), and this flooring surface has been associated with an increased incidence of lameness and hoof

Received January 18, 2010.

Accepted October 4, 2010.

${ }^{1}$ Corresponding author: cbtucker@ucdavis.edu problems (e.g., Vokey et al., 2001; Cook, 2003; Somers et al., 2003). In addition to influencing hoof health, concrete flooring can impair locomotion (Jungbluth et al., 2003; Rushen et al., 2004; van der Tol et al., 2005) and reduce expression of estrus behavior (Phillips and Schofield, 1994; Lopez and Shipka, 2003) and caudal licking (Jungbluth et al., 2003). Cattle show distinct preferences for softer flooring for lying and standing (Lowe et al., 2001; Manninen et al., 2002; Tucker and Weary, 2004). Together these results indicate that concrete is uncomfortable.

In light of these issues, an increasing amount of research is focused on alternative flooring surfaces in dairy barns, particularly surfaces that are more compressible and have higher friction than concrete. Given that cattle spend 4 to $6 \mathrm{~h} / \mathrm{d}$ eating in freestall barns, replacing the concrete flooring in front of feed bunks may be especially beneficial. Fregonesi et al. (2004), Tucker et al. (2006), and Boyle et al. (2007) found that dairy cows spent more time standing near the feed bunk on a rubber or sawdust surface compared with concrete. Others have found that cows housed on rubber floors throughout the freestall environment were more active and spent more time standing than cows kept on concrete, indicating that they are more comfortable on rubber (Platz et al., 2008; Haufe et al., 2009; Ouweltjes et al., 2009). Cows walked faster and with longer strides, and slipped less often, on softer rubber floors compared with concrete floors (Jungbluth et al., 2003; Telezhenko and Bergsten, 2005), and took fewer steps to traverse an alley way covered with a surface 10 times more compressible than concrete (Rushen and de Passillé, 2006). When walking, cows also choose floors that have more traction (Phillips and Morris, 2001). Little is known, however, about which of these flooring design features (e.g., compressibility, friction) are important for standing surfaces in front of the feeder.

Evidence exists that restless behavior may be a useful tool in the assessment of comfort while standing. When forced to stand on concrete after morning milking, as is common when awaiting artificial insemination or veterinary treatment, cows move their hooves more with increased standing time (Cooper et al., 2007, 2008). Increased variation in distribution of BW has also been 
used to detect uncomfortable standing surfaces, such as those with protruding rocks or screws, compared with rubber flooring (Neveux et al., 2006). Other evidence supports the idea that restless behavior serves as a measure of discomfort. Lame cattle shift their weight more than sound cows while standing (Pastell and Kujala, 2007), and this behavior is reduced when lame cows are given pain relief (Rushen et al., 2007).

It is unclear, however, if restless behavior can be used to detect differences in the comfort of specific design features, such as compressibility, of flooring surfaces. Our objective was to assess how behavior, specifically restless behavior, as measured by the number of steps, changed in response to concrete and more compressible rubber flooring during $4 \mathrm{~h}$ of forced standing.

\section{MATERIALS AND METHODS}

\section{General Information}

Two experiments (Exp.) were conducted at the University of California, Davis, dairy facilities between July and August 2007 (Exp. 1) and between February and May 2008 (Exp. 2). In Exp. 1, the average daily temperature was $25.5^{\circ} \mathrm{C}$ and the average relative humidity was $44.8 \%$; in Exp. 2, the average daily temperature was $13.2^{\circ} \mathrm{C}$ and the average relative humidity was $65.4 \%$ (Western Regional Climate Center, Reno, $\mathrm{NV}$, located $33.8 \mathrm{~km}$ northeast of the experimental site). All procedures were approved by the Institutional Animal Care and Use Committee.

\section{Animals and Housing}

Thirty-two lactating Holstein-Friesian dairy cows were divided into 4 groups of 4 for each experiment. All 16 cows in Exp. 1 were pregnant [(mean $\pm \mathrm{SD})$ : $\mathrm{BW}=$ $474 \mathrm{~kg} \pm 65 ; \mathrm{BCS}=2.7 \pm 0.35 ; \mathrm{DIM}=121 \pm 28$; days carrying calf $=34 \pm 30]$. In Exp. 2, 16 cows were used and 13 were pregnant [(mean $\pm \mathrm{SD}): \mathrm{BW}=497.2 \mathrm{~kg} \pm$ $66.2 ; \mathrm{BCS}=3.07 \pm 0.25 ; \mathrm{DIM}=124 \pm 15$; days carrying calf for the 13 pregnant cows $=52 \pm 11$ ]. The cows were milked twice daily at 0700 and $1900 \mathrm{~h}$ and fed ad libitum with TMR formulated using the PC Dairy system (Bath and Strasser, 1990) for cows producing 43 $\mathrm{kg} / \mathrm{d}$ of milk with 3.7 to $3.8 \%$ fat. The diet was $60.6 \%$ $\mathrm{DM}$ as fed and $18.8 \% \mathrm{CP}, 21.5 \% \mathrm{ADF}$ and $28.5 \% \mathrm{NDF}$ (DM basis, Exp. 1) and 66.4\% DM as fed and $15.4 \%$ CP, $24.0 \%$ ADF, and 29.6\% NDF (DM basis, Exp. 2). Time spent in the milking parlor was relatively short; although not measured in these experiments, it was 12 \pm 2.8 min (mean $\pm \mathrm{SD}$ ) in comparable work carried out by our group. Experimental animals were kept separate from the rest of the herd at this time.
Cows were individually housed in experimental pens that contained 2 sections: a deep-bedded area and a concrete area in front of the feed bunk. The deepbedded area measured $4.45 \times 3.86 \mathrm{~m}$, was bedded with rice hulls ( $0.20 \mathrm{~m}$ deep), and contained a water trough. The concrete area in front of the feed bunk was divided into 3 sections (each $2.44 \mathrm{~m} \times 1.16 \mathrm{~m}$ ) and each section had a metal feed bunk $(0.84 \times 0.76 \mathrm{~m})$ at the front. The 3 sections were separated by custom-made dividers similar to freestall loops (Cal Coast Inc., Turlock, CA). Plywood partitions $(0.90 \times 1.1 \mathrm{~m})$ were placed on the dividers to prevent cows from feeding from the adjacent bin. Four experimental pens were used, thus to test all 16 animals, the study was replicated over time.

\section{Experimental Procedures}

Three flooring surfaces were tested in each experiment. Experiment 1 compared concrete, a single-layer of revulcanized rubber (Animat, Animat Inc., SaintÉlie d'Orford, Quebec, Canada, $19 \mathrm{~mm}$ thick, $2 \times$ as compressible as concrete; $\mathbf{2} \times$ treatment), and a doublelayer of revulcanized rubber (Animat, $38 \mathrm{~mm}$ thick, $4 \times$ as compressible as concrete; $4 \times$ treatment). The concrete and $4 \times$ were also used in Exp. 2, and the third treatment in this experiment was a PastureMat (Promat Inc., Seaforth, Ontario, Canada, $75 \mathrm{~mm}$ thick) underneath a single layer of Animat rubber (resulting in a surface that was $94 \mathrm{~mm}$ thick and $35 \times$ as compressible as concrete; $35 \times$ treatment). The degree of compressibility of the surfaces (Table 1) was tested by Anamet Inc. (Hayward, CA) using a modified ASTM D575 standard engineering technique (ASTM, 1991). All surfaces except for the concrete had similar traction and visual appearance.

Cows were given $24 \mathrm{~h}$ to habituate to the experimental pens; during this period, they were fed from all 3 feed bunks in front of the 3 treatments. The treatments were tested on 3 consecutive days for Exp. 1, and on 3 d each separated by 1 rest day in Exp. 2. On each test day, cows were restricted to standing on a single flooring surface for $4 \mathrm{~h}$ after morning milking. Two horizontal iron bars held by plywood structures attached to the freestall loops prevented cows from moving backward but allowed them to stand with their head either in or out of the feed bunk. This restriction was designed to simulate forced standing associated with waiting for veterinary treatment or artificial insemination. In contrast to normal farm practice, the head of the animal was not restrained to allow access to water. Water was provided in buckets next to the feed bunk, but outside of the freestall loops, during all periods of forced standing. Cows were separated from the feed bunk by head gates. As on rest days (Exp. 2 only), cows 
2008). For this analysis, these data were divided into the smallest unit of time that seemed reasonable for the given sampling method: 1 value/h for steps and 1 value/30 min for head position. The model included a term for cow $(15 \mathrm{df})$ and tested treatment $(1 \mathrm{df})$ against an error term with $15 \mathrm{df}$. The effect of time was tested with the Greenhouse-Geisser correction. One cow was excluded from the time spent with the head in the feed bunk in Exp. 1 because of observer error. Each experiment was considered separately.

Dry matter intake, time spent with the head in the feed bunk (during overall 24 h, Exp. 2 only), and latency to lie (Exp. 2 only) were compared with paired $t$-tests (PROC GLM; SAS Institute, 2008) with an error term with $15 \mathrm{df}$ as described above. Two cows were excluded from the latency-to-lie analysis; one was removed from the pen for veterinary treatment and the second lay down during the last $10 \mathrm{~min}$ of forced standing (giving a latency-to-lie value of $<0$ ). Each experiment was considered separately.

Pearson correlations were used to explore the relationship between hoof size, BW, and gait score and the response to treatments (SAS Institute, 2008). The response to treatment was calculated as the difference between the average steps/min taken on each pair of treatments for each cow (for example, Exp. 2: 35× vs. $4 \times, 4 \times$ vs. concrete, $35 \times$ vs. concrete). This correlation analysis was done separately for each experiment.

Pearson correlations were also used to explore the relationship between stepping rate (steps/min during

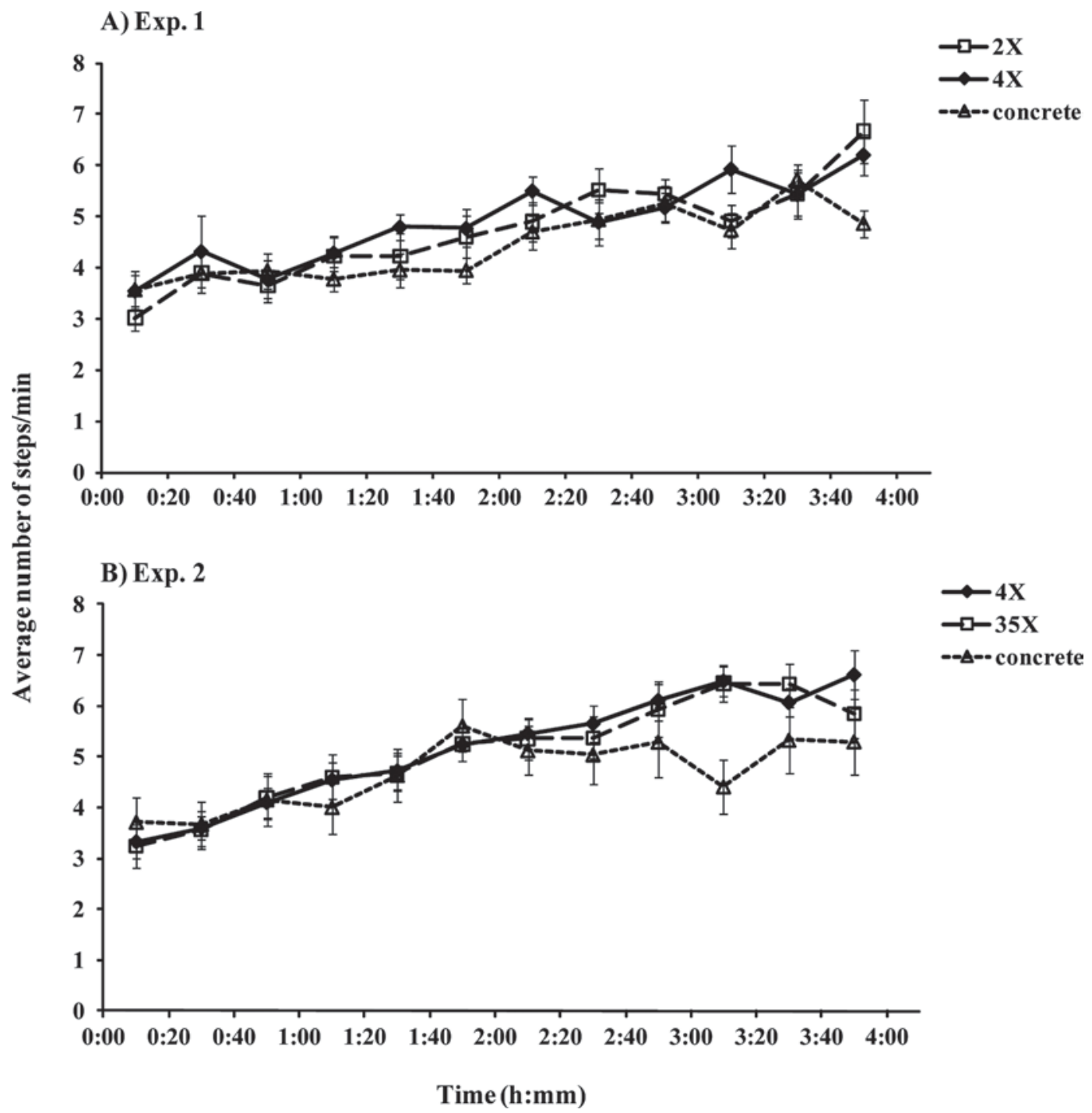

Figure 1. Average number of steps per min over $4 \mathrm{~h}$ of forced standing on 3 surfaces in experiments (Exp.) 1 and 2 (n = 16/experiment). In both experiments, concrete was compared with a rubber surface that was $2(2 \times$, Exp. 1), 4 (4×, Exp. 1 and 2$)$, or 35 times (35×, Exp. 2$)$ more compressible than concrete. 
$4 \mathrm{~h}$ of forced standing) and hoof size, BW, gait score, and time spent with the head in the feed bunk. All 32 animals were combined in this analysis, and stepping rates (steps/min) from the $4 \times$ treatment were used.

Finally, the effect of hoof health on stepping rate on the $4 \times$ surface and response to treatment (as measured by the difference between the $4 \times$ and concrete treatments) was explored with $t$-tests (PROC GLM). These dependent variables were chosen because they were common to both experiments. Cows were classified by the presence or absence of a sole hemorrhage $(\mathrm{n}=22$ with and $\mathrm{n}=10$ without) or a white line fissure ( $\mathrm{n}=$ 24 with and $n=10$ without), and separate tests were run for these 2 types of injury. Some animals also had both sole hemorrhages and white line fissures, but the sample size was too small to warrant statistical comparison for this combination (only $\mathrm{n}=4$ without either injury) or for sole ulcers $(\mathrm{n}=0)$. The $P$-values reported are from the Welch test to address the unequal sample size associated with hoof health.

\section{RESULTS}

During the 4-h period of forced standing in Exp. 1 and across all treatments, the total number of steps increased from $3.7 \pm 0.3$ steps $/ \mathrm{min}$ in the first hour to $5.5 \pm 0.3 \mathrm{steps} / \mathrm{min}$ in the fourth hour $(P<0.001$, Figure 1A). Experiment 2 produced very similar results with $3.7 \pm 0.3$ total steps/min during the first hour increasing to $5.9 \pm 0.4$ total steps/min during the fourth hour across all treatments $(P<0.001$, Figure 1B). No differences in stepping behavior were observed between the flooring treatments in either experiment $(P \geq 0.102)$.

The overall amount of time cows spent with their heads in the feed bunk decreased across the $4 \mathrm{~h}$ of forced standing for both Exp. 1 and $2(P \leq 0.044)$. In the first 30 min of the forced standing in Exp. 1, cows spent $87.3 \pm 3.4 \%$ of their time with their heads in the feed bunk, compared with $72.2 \pm 5.6 \%$ in the final $30 \mathrm{~min}$ (Figure 2). A similar pattern for time spent with the head in the feed bunk was found in Exp. 2: cows spent $87.2 \pm 3.2 \%$ of their time in the first $30 \mathrm{~min}$ with their head in the feed bunk, and only $76.7 \pm 4.2 \%$ in the final 30 min (Figure 2). As with stepping behavior, no differences were observed between any of the treatments with respect to behavior directed toward the feed bunk, including average daily DMI (time with head in during 4-h of forced standing or over $24 \mathrm{~h}$ in both experiments: $P \geq 0.248$; DMI: Exp. 1: concrete: $24.0 \pm 1.2 \mathrm{~kg}, 2 \times$ : $23.6 \pm 1.0 \mathrm{~kg}, 4 \times: 23.1 \pm 1.0 \mathrm{~kg}$; Exp. 2 : concrete: 26.4 $\pm 0.6 \mathrm{~kg}, 4 \times: 27.6 \pm 0.6 \mathrm{~kg}, 35 \times: 27.4 \pm 0.8 \mathrm{~kg} ; P \geq$ $0.120)$. After cows were released from the $4 \mathrm{~h}$ of forced standing, no difference was found in the latency to lie down (Exp. 2: concrete: $3.9 \pm 0.84$ min, $4 \times: 4.2 \pm 0.96$ $\min , 35 \times: 5.4 \pm 0.93 \mathrm{~min} ; P \geq 0.136)$.

In both experiments, cow size (determined by BW and hoof surface area) may have influenced the response

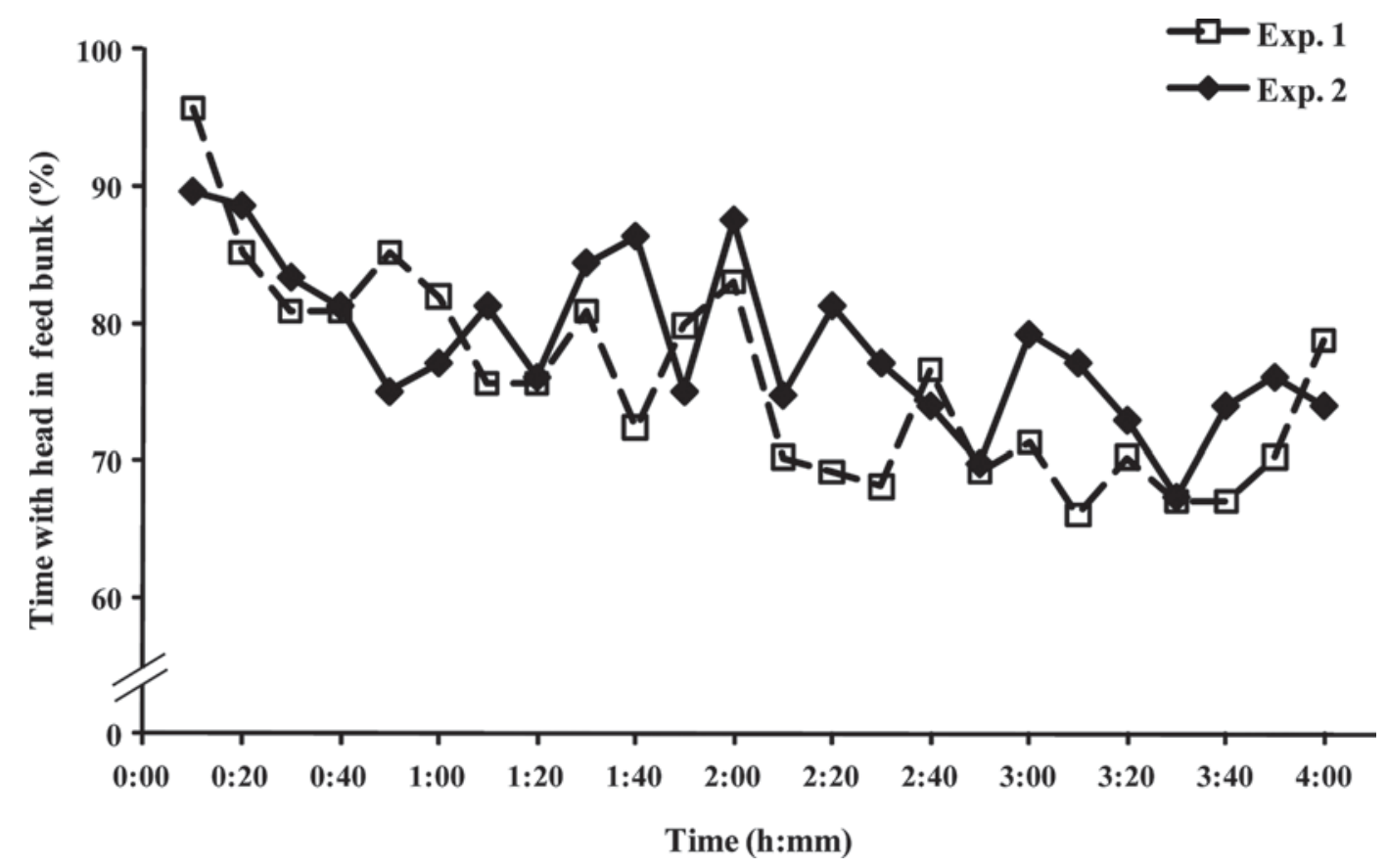

Figure 2. Percentage of time spent with head in the feed bunk during $4 \mathrm{~h}$ of forced standing in experiments (Exp.) 1 and 2 (n $=16 /$ experiment). 
to treatment. To test this idea, correlation coefficients were calculated using the difference in average number of steps/min in each pair of treatments. Heavier cows stepped more on $4 \times$ than on concrete compared with lighter weight cows in Exp. $1(\mathrm{r}=0.752, P=0.001)$ but not in Exp. $2(\mathrm{r}=-0.156, P=0.565$, Figure 3A). Similarly, cows with a higher gait score tended to step more on $4 \times$ than on concrete in Exp. $1(\mathrm{r}=0.453, P$ $=0.092)$, but not in Exp. $2(\mathrm{r}=-0.281, P=0.292$, Figure 3B). Hoof surface area was not correlated with any difference in response to treatment in either experiment $(P \geq 0.533)$.
Cow BW, hoof size, gait score, and time spent standing with the head in the feeder did not correlate with stepping rate on the $4 \times$ surface $(\mathrm{n}=32 ; \mathrm{r}=0.192$, $0.072,-0.020$, and 0.224 , respectively; $P \geq 0.224$ ). Similarly, the presence of a sole hemorrhage or white line fissure did not affect the response to treatment (4x vs. concrete) or stepping rate on the $4 \times$ surface ( $\mathrm{n}=$ 32; Table 2).

\section{DISCUSSION}

Cows increased restless behavior during $4 \mathrm{~h}$ of forced standing after the morning milking. As time went on,

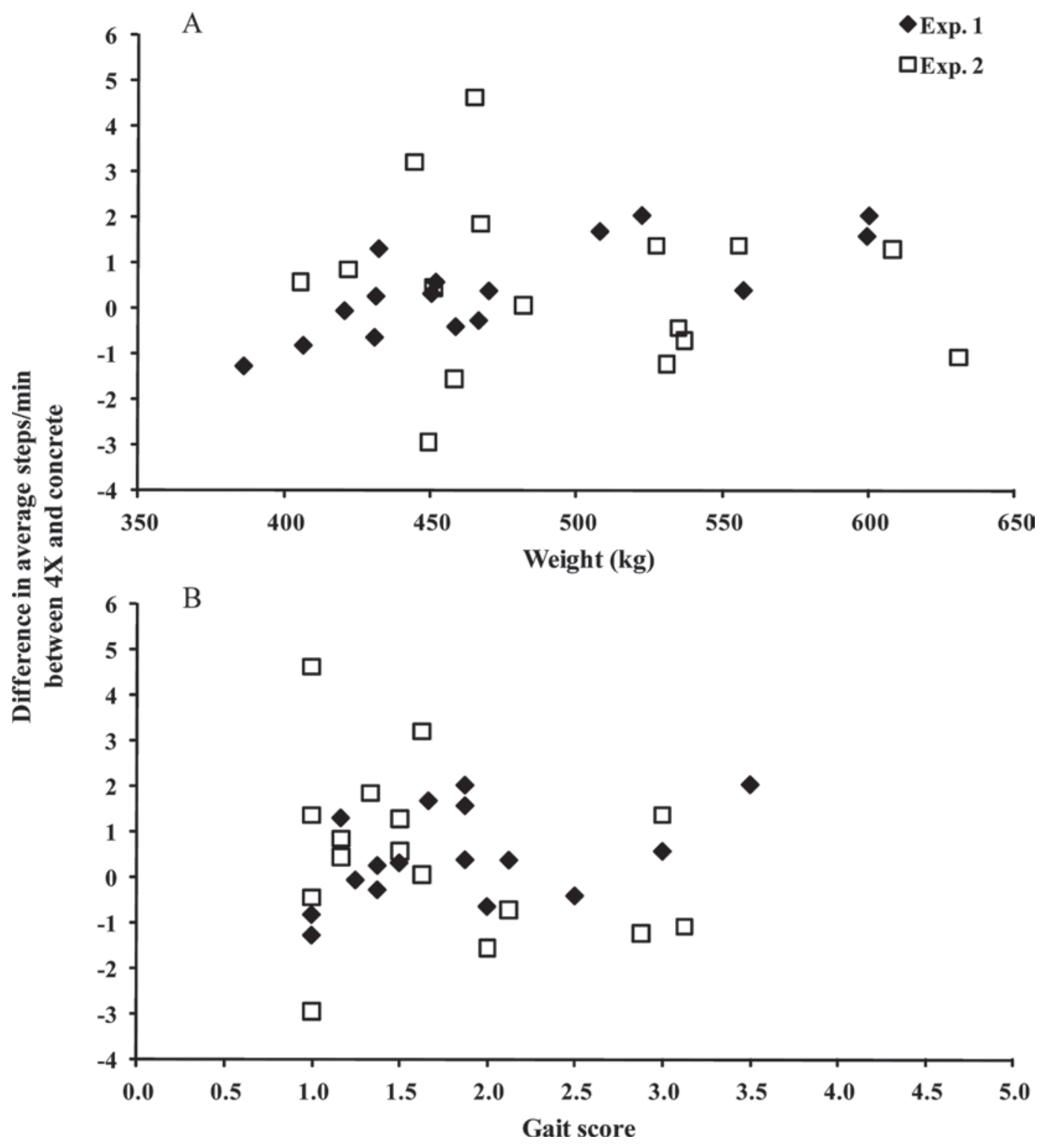

Figure 3. The difference between the average total number of steps/minute on concrete and $4 \times$ (a rubber surface 4 times as compressible as concrete) plotted against cow weight (panel A) and gait score (panel B, scored on a 5-point scale) in experiments (Exp.) 1 and 2 (n = 16/ experiment). 
Table 2. Sample size, response to treatment (difference between $4 \times$ and concrete in step/min), and stepping rate (steps/min) in relation to the presence or absence of a sole hemorrhage and white line fissure ${ }^{1}$

\begin{tabular}{|c|c|c|c|}
\hline \multirow[b]{2}{*}{ Item } & \multicolumn{2}{|c|}{ Injury } & \multirow[b]{2}{*}{$P$-value } \\
\hline & Yes & No & \\
\hline \multicolumn{4}{|l|}{ Sole hemorrhage } \\
\hline $\mathrm{n}$ & 22 & 10 & - \\
\hline Response to treatment $(4 \times-$ concrete $)$, steps $/ \min$ & $5.4 \pm 3.2$ & $3.2 \pm 4.8$ & 0.637 \\
\hline Steps $/ \min$ on $4 \times$ & $4.8 \pm 0.2$ & $4.7 \pm 0.3$ & 0.772 \\
\hline \multicolumn{4}{|l|}{ White line fissure } \\
\hline $\mathrm{n}$ & 24 & 8 & - \\
\hline Response to treatment $(4 \times-$ concrete $)$, steps $/ \min$ & $2.1 \pm 2.9$ & $12.4 \pm 5.1$ & 0.185 \\
\hline Steps/min on $4 \times$ & $4.8 \pm 0.2$ & $4.7 \pm 0.3$ & 0.869 \\
\hline
\end{tabular}

cows took more steps/minute and were less likely to have their heads in the feed bunk. This behavioral response was not affected by the flooring type or compressibility, nor did it consistently differ with hoof health or cow size.

The increase in stepping rate over the $4 \mathrm{~h}$ of forced standing was similar in both of the current experiments. Others have also found that stepping increases over 2 and $4 \mathrm{~h}$ of forced standing (Cooper et al., 2007, 2008), although the magnitude of restless behavior differs markedly between experiments. For example, Cooper et al. (2007) reported a median 0.1 steps $/ \mathrm{min}$ during $4 \mathrm{~h}$ of forced standing. This is considerably less than the average 3.7 steps $/ \mathrm{min}$ seen in the first hour of restraint in the current experiments. Of the studies reporting stepping rate for all 4 hooves, the current results from the first hour of standing are similar to the measurements from Hagen et al. (2004) and Kendall et al. (2007) during or before milking. Differences in both the behavioral definitions and the method of observation used to measure stepping rate may account for some of the variation between studies (Table 3), but the very low levels of stepping in some experiments are difficult to explain.

The increase in restless behavior over time could be interpreted as an increase in discomfort. Two types of evidence support this idea. The very short latency to lie down after the end of the $4 \mathrm{~h}$ (on average, $4.5 \mathrm{~min}$ ) indicates that the cows did not want to continue standing. Similarly, when restrained in headlocks for $4 \mathrm{~h}$, cows spent more time lying down in the following $20 \mathrm{~h}$ than cows that had not undergone this forced period of standing (Bolinger et al., 1997). Second, shifting weight increases with exposure to rocky surfaces (Neveux et al., 2006) and pain associated with lameness (Rushen et al., 2007).

In contrast to these previous studies, we found no difference in restless behavior between types of flooring (concrete vs. rubber) or its compressibility $(2,4$, and $35 \times$ more compressible than concrete) in the current experiments. These results disagree with our prediction, based on the increase in weight shifting as measured with load cells seen in response to short-term exposure to a rocky, and likely uncomfortable, surface under a single hoof (Neveux et al., 2006), that cows would reduce restless behavior on rubber or more compressible surfaces. It could be that, to evaluate the relative comfort of a surface, the treatment of interest should be placed only under a single hoof to allow the cow to move her weight to or from this option, as in Neveux et al. (2006). Similarly, it is unclear if the number of steps taken is equivalent to variation in BW measured with load cells in these other studies.

There is growing evidence that, using indicators other than restless behavior, rubber flooring in front of the feed bunk is more comfortable than concrete. Cows will spend between 0.7 and $4.2 \%$ more time on rubber flooring in this area, compared with concrete (Fregonesi et al., 2004; Tucker et al., 2006; Boyle et al., 2007). In addition, in housing systems with only a limited amount of rubber flooring, dominant cows spent more time on rubber compared with subordinate animals (Platz et al., 2007). This indicates that the rubber surfaces are a distinguishable and valuable resource. Others have found that cows housed on rubber floors throughout the freestall environment were more active and spent more time standing than cows kept on concrete, indicating that they are more comfortable on rubber (Platz et al., 2008; Haufe et al., 2009; Ouweltjes et al., 2009). Indeed, cattle slip less and take longer strides when walking on rubber compared with concrete (Telezhenko and Bergsten, 2005; Flower et al., 2007). These findings suggest that rubber flooring may be more comfortable for active behaviors, such as walking. If this is the case, flooring compressibility may be less important while standing. Future studies evaluating flooring in front of 


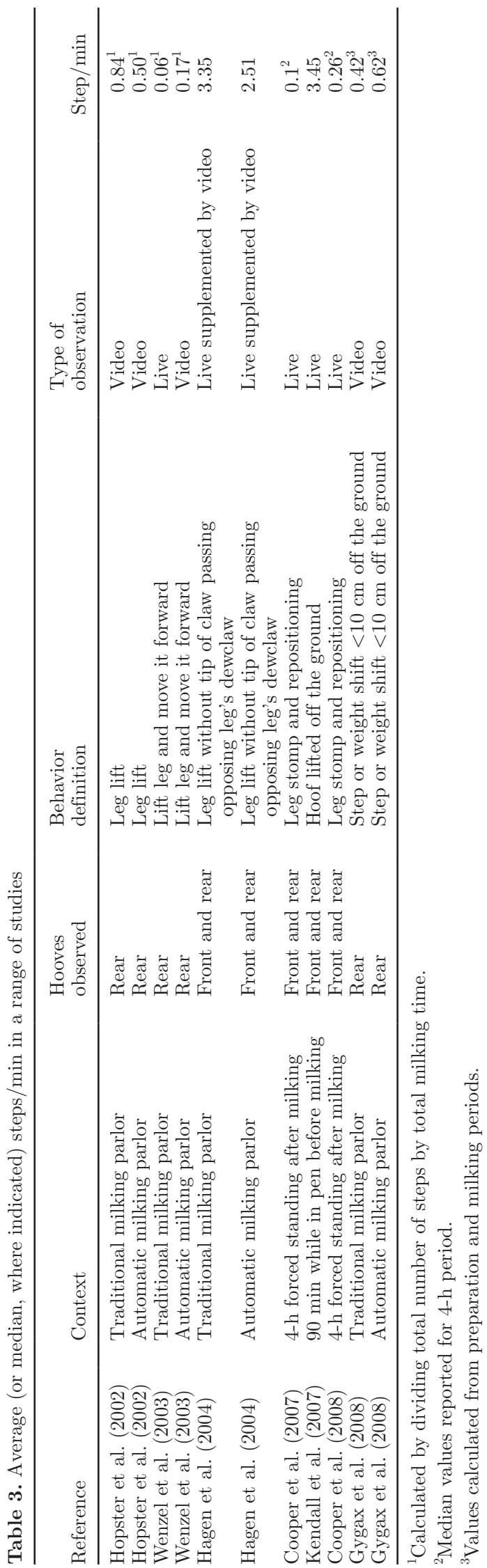

the feed bunk should consider recording measures of activity in addition to time spent on the surface.

Previous work has found that animals that are lame or have hoof injuries have improved gait or walking patterns on rubber and that these differences are more marked than in healthy animals (Telezhenko and Bergsten, 2005; Flower et al., 2007). In the current work, no consistent effect of BW, hoof size, hoof health, or gait score was found on the response to the flooring treatments. In Exp.1 heavier cows and those with a higher gait score took more steps on the $4 \times$ surface than on concrete, but these patterns were not in the expected direction, nor were they repeated in Exp. 2. The experimental animals were relatively healthy, with no sole ulcers, and had relatively low gait scores: 1.8 on a 5-point scale, on average, and none of the animals had an obvious limp. It is possible that more compressible flooring may only be important to animals with more severe health problems than those tested in the current experiments.

\section{CONCLUSIONS}

Restless behavior increased during $4 \mathrm{~h}$ of forced standing after morning milking. Limited evidence shows that $4 \mathrm{~h}$ of standing is uncomfortable, in that cows lay down within minutes when given access to the lying area. No differences were found in restless or other behaviors associated with the type or compressibility of the flooring surface in front of the feed bunk. It is unclear if comfort did not differ between these options during $4 \mathrm{~h}$ of forced standing or if alterative methodology, such as measuring more subtle shifts in weight, is required to detect such differences.

\section{ACKNOWLEDGMENTS}

We are grateful to David Ledgerwood and Amanda Grout (UC Davis) for their invaluable help in running these experiments. We also thank Animat Inc. (SaintÉlie d'Orford, Québec, Canada) and Promat Inc. (Seaforth, Ontario, Canada) for their in-kind donations in support of this work.

\section{REFERENCES}

ASTM. 2007. ASTM D575-91. Standard test methods for rubber properties in compression. http://www.astm.org/index.shtml.

Bath, D. L., and S. J. Strasser. 1990. A computer program for formulating nutritional and economic rations for dairy operations. Vet. Med. 85:1334.

Bolinger, D. J., J. L. Albright, J. Morrow-Tesch, S. J. Kenyon, and M. D. Cunningham. 1997. The effects of restraint using self-locking stanchions on dairy cows in relation to behavior, feed intake, physiological parameters, health, and milk yield. J. Dairy Sci. 80:2411-2417. 
Boyle, L. A., J. F. Mee, and P. J. Kiernan. 2007. The effect of rubber versus concrete passageways in cubicle housing on claw health and reproduction of pluriparous dairy cows. Appl. Anim. Behav. Sci. 106:1-12.

Cook, N. B. 2003. Prevalence of lameness among dairy cattle in Wisconsin as a function of housing type and stall surface. J. Am. Vet. Med. Assoc. 223:1324-1328.

Cooper, M. D., D. R. Arney, and C. J. C. Phillips. 2007. Two- or fourhour lying deprivation on the behavior of lactating dairy cows. J. Dairy Sci. 90:1149-1158.

Cooper, M. D., D. R. Arney, and C. J. C. Phillips. 2008. The effect of temporary deprivation of lying and feeding on the behaviour and production of lactating dairy cows. Animal 2:275-283.

Ferguson, J. D., D. T. Galligan, and N. Thomsen. 1994. Principal descriptors of body condition score in Holstein cows. J. Dairy Sci. 77:2695-2703.

Flower, F. C., A. M. de Passillé, D. M. Weary, D. J. Sanderson, and J. Rushen. 2007. Softer, higher-friction flooring improves gait of cows with and without sole ulcers. J. Dairy Sci. 90:1235-1242.

Flower, F. C., and D. M. Weary. 2006. Effect of hoof pathologies on subjective assessments of dairy cow gait. J. Dairy Sci. 89:139 146.

Fregonesi, J. A., C. B. Tucker, D. M. Weary, F. C. Flower, and T. Vittie. 2004. Effect of rubber flooring in front of the feed bunk on the time budgets of dairy cattle. J. Dairy Sci. 87:1203-1207.

Gygax, L., I. Neuffer, C. Kaufmann, R. Hauser, and B. Wechsler. 2008. Restlessness behaviour, heart rate and heart-rate variability of dairy cows milked in two types of automatic milking systems and auto-tandem milking parlours. Appl. Anim. Behav. Sci. 109:167-179.

Hagen, K., D. Lexer, R. Palme, J. Troxler, and S. Waiblinger. 2004 Milking of Brown Swiss and Austrian Simmental cows in a herringbone parlour or an automatic milking unit. Appl. Anim. Behav. Sci. 88:209-225.

Haufe, H. C., L. Gygax, B. Steiner, K. Friedli, M. Stauffacher, and B. Wechsler. 2009. Influence of floor type in the walking area of cubicle housing systems on the behaviour of dairy cows. Appl. Anim. Behav. Sci. 116:21-27.

Hopster, H., R. M. Bruckmaier, J. T. N. Van der Werf, S. M. Korte, J. Macuhova, G. Korte-Bouws, and C. G. van Reenen. 2002. Stress responses during milking; Comparing conventional and automatic milking in primiparous dairy cows. J. Dairy Sci. 85:3206-3216.

Jungbluth, T., B. Benz, and H. Wandel. 2003. Soft walking areas in loose housing systems for dairy cows. Pages 171-177 in 5th Int. Dairy Housing Conf., Fort Worth, TX. K. Janni, ed. Am. Soc. Agric. Eng., St. Joseph, MI.

Kendall, P. E., G. A. Verkerk, J. R. Webster, and C. B. Tucker. 2007. Sprinklers and shade cool cows and reduce insect-avoidance behavior in pasture-based dairy systems. J. Dairy Sci. 90:3671-3680.

Lopez, H., and M. P. Shipka. 2003. Association of flooring surface to estrous behavior in lactating dairy cows as determined by radiotelemtric estrous detection. Pages 296-302 in 5th Int. Dairy Housing Conf., Fort Worth, TX. K. Janni, ed. Am. Soc. Agric. Eng., St. Joseph, MI.

Lowe, D. E., R. W. J. Steen, and V. E. Beattie. 2001. Preferences of housed finishing beef cattle for different floor types. Anim. Welf. 10:395-404.

Manninen, E., A. M. de Passillé, J. Rushen, M. Norring, and H. Saloniemi. 2002. Preferences of dairy cows kept in unheated buildings for different kind of cubicle flooring. Appl. Anim. Behav. Sci. $75: 281-292$.
Neveux, S., D. M. Weary, J. Rushen, M. A. G. von Keyserlingk, and A. M. de Passillé. 2006. Hoof discomfort changes how dairy cattle distribute their body weight. J. Dairy Sci. 89:2503-2509.

Ouweltjes, W., M. Holzhauer, P. P. J. van der Tol, and J. van der Werf. 2009. Effects of two trimming methods of dairy cattle on concrete or rubber-covered slatted floors. J. Dairy Sci. 92:960-971.

Pastell, M. E., and M. Kujala. 2007. A probabilistic neural network model for lameness detection. J. Dairy Sci. 90:2283-2292.

Phillips, C. J. C., and I. D. Morris. 2001. The locomotion of dairy cows on floor surfaces with different frictional properties. J. Dairy Sci. 84:623-628.

Phillips, C. J. C., and S. A. Schofield. 1994. The effect of cubicle and straw yard housing of the behaviour, production and hoof health of dairy cows. Anim. Welf. 3:37-44.

Platz, S., F. Ahrens, J. Bendel, H. Meyer, and M. H. Erhard. 2007. Rank correlated use of soft flooring by dairy cattle. Anim. Welf. $16: 255-257$.

Platz, S., F. Ahrens, J. Bendel, H. H. D. Meyer, and M. H. Erhard. 2008. What happens with cow behavior when replacing concrete slatted floor by rubber coating: A case study. J. Dairy Sci. 91:999-1004.

Rushen, J., and A. M. de Passillé. 2006. Effects of roughness and compressibility of flooring on cow locomotion. J. Dairy Sci. 89:29652972.

Rushen, J., A. M. de Passillé, F. Borderas, C. Tucker, and D. Weary. 2004. Designing better environments for cows to walk and stand. Pages 55-64 in Adv. in Dairy Technol. Vol. 16. J. Kennelly, ed. Univ. Alberta, Red Deer, Alberta, Canada.

Rushen, J., E. Pombourcq, and A. M. de Passillé. 2007. Validation of two measures of lameness in dairy cows. Appl. Anim. Behav. Sci. 106:173-177.

SAS Institute. 2008. Version 9.12 Edition. SAS Institute Inc., Cary, $\mathrm{NC}$

Somers, J. G. C. J., K. Frankena, E. N. Noordhuizen-Stassen, and J. H. M. Metz. 2003. Prevalence of claw disorders in Dutch dairy cows exposed to several floor systems. J. Dairy Sci. 86:2082-2093.

Telezhenko, E., and C. Bergsten. 2005. Influence of floor type on the locomotion of dairy cows. Appl. Anim. Behav. Sci. 93:183-197.

Tucker, C. B., and D. M. Weary. 2004. Bedding on geotextile mattresses: How much is needed to improve cow comfort? J. Dairy Sci. 87:2889-2895.

Tucker, C. B., D. M. Weary, A. M. de Passillé, B. Campbell, and J. Rushen. 2006. Flooring in front of the feed bunk affects feeding behavior and use of freestalls by dairy cows. J. Dairy Sci. 89:2065-2071.

USDA. 2007. Part I: Reference of dairy health and management in the United States. USDA:APHIS:VS, CEAH, National Animal Health Monitoring System, Fort Collins, CO.

van der Tol, P. P. J., J. H. M. Metz, E. N. Noordhuizen-Stassen, W. Back, C. R. Braam, and W. A. Weijs. 2005. Frictional forces required for unrestrained locomotion in dairy cattle. J. Dairy Sci 88:615-624.

Vokey, F. J., C. L. Guard, H. N. Erb, and D. M. Galton. 2001. Effects of alley and stall surfaces on indices of claw and leg health in dairy cattle housed in a free-stall barn. J. Dairy Sci. 84:2686-2699.

Wenzel, C., S. Schonreiter-Fischer, and J. Unshelm. 2003. Studies on step-kick behavior and stress of cows during milking in an automatic milking system. Livest. Prod. Sci. 83:237-246. 